\title{
EFFECT OF CORTISONE ON THE PERMEABILITY OF THE BLOOD-AQUEOUS BARRIER TO [FLUORESCEIN
}

\author{
BY \\ CHARLES COOK AND R. K. MACDONALD \\ From the Institute of Ophthalmology, London
}

THE unsatisfactory state of our knowledge regarding the effect of cortisone on capillary permeability has been discussed in a previous paper (Duke-Elder and Ashton, 1951). It was there noted that Leopold and others (1951), injecting fluorescein intravenously in rabbits and estimating its concentration in the aqueous humour, observed no delay in the appearance of the dye in the anterior chambers of cortisone-treated animals in comparison with normal controls. From this it may be concluded that cortisone has no effect on the permeability of the capillaries in the normal eye, for molecules of the size of fluorescein. We have confirmed these negative findings by the use of the same method with a slightly modified technique. In our experiments an intravenous injection of $0.05 \mathrm{ml} .10$ per cent. fluorescein was given, and cortisone was injected both intramuscularly $(0.5 \mathrm{ml}$. of $25 \mathrm{mg} . / \mathrm{ml}$. solution $)$ and subconjunctivally $(0.25 \mathrm{ml}$. of $25 \mathrm{mg}$. $/ \mathrm{ml}$. solution).

We have extended their investigations to explore the effect of cortisone on the capillary permeability in human eyes in which inflammatory manifestations were present and also in those in which it was absent.

\section{Method}

A series of ten cases, comprising a variety of ocular inflammatory conditions, was treated with cortisone. In each case a capillary permeability test was done both before and during cortisone therapy, and in six cases a further test was carried out after cessation of cortisone treatment at periods varying from 2 to 9 weeks. The relative concentrations of fluorescein entering the anterior chamber were estimated and recorded on the Amsler-Huber Chart. A fluorescein permeability curve for both eyes was thus obtained on each occasion.

Owing to the physical limitations of the method used, only the relative fluorescein concentrations represented in ampères may be 
recorded. Comparison of the resulting curves may, therefore, be misleading. However, a conversion curve has been calculated experimentally, by means of which these readings may be converted from ampères to absolute concentrations of fluorescein (Fig. 1).

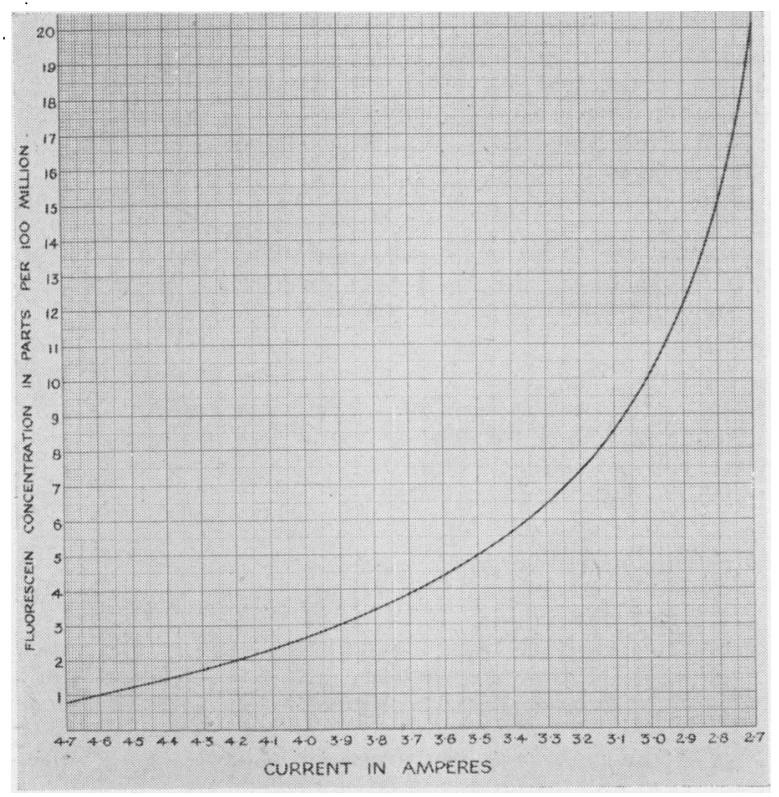

FIG. 1.-Conversion curve translating relative concentrations of fluorescein (as ampères) into ąbsolute concentrations of fluorescein.

\section{Case Histories}

Case 1, R. H., aged 38 years.

Diagnosis.-Acute choroiditis of right eye of 3 weeks' duration.

Condition before Treatment.- The eye was white but a faint aqueous flare and several minute keratic precipitates were present. There was a moderate vitreous haze. A large area of active choroiditis was present nasally to the disk.

Treatment. $-200 \mathrm{mg}$. cortisone given intramuscularly on the first day, and $100 \mathrm{mg}$. daily thereafter divided into two doses.

Course.-The aqueous flare disappeared in 2 days, the vitreous was clear in 9 days, and the focus appeared to be inactive in 2 weeks. The lesion has remained quiescent since the cessation of cortisone therapy.

Case 2, R. A., aged 22 years.

Diagnosis.-Bilateral perivasculitis retinae of six months' duration.

Condition before Treatment.-The right eye showed a marked ciliary injection and a faint aqueous flare was present. There was a dense vitreous haze which obscured the fundus. The left eye was white and the anterior chamber clear but there was a dense vitreous haze which obscured the fundus details.

Treatment. $-200 \mathrm{mg}$. cortisone intramuscularly on the first day. Thereafter $100 \mathrm{mg}$. daily divided into two doses.

Course.-There was a rapid clearing of the vitreous haze in both eyes and the fundus details became visible after seven days. The fundus showed extensive perivascular retinal haemorrhages and exudates in addition to retinitis proliferans. There was no apparent change in the fundus after cortisone therapy. 
Case 3, J. C., aged 16 years.

Diagnosis.-Acute choroiditis in the right eye of 6 weeks' duration.

Condition before Treatment.- The eye was white and the anterior chamber clear. A diffuse vitreous haze was present but a small focus of active choroiditis was visible above the macula.

Treatment. $-80 \mathrm{mg}$. cortisone intramuscularly on the first day. Thereafter $50 \mathrm{mg}$. daily divided into two doses.

Course...-The vitreous was completely clear and the focus appeared inactive in 10 days.

Case 4, L. K., aged 26 years.

Diagnosis.-Acute choroiditis of right eye of 12 weeks' duration.

Condition before Treatment.--The eye was mildly injected and a marked aqueous flare was present. There was a dense vitreous haze but a large focus of active choroiditis was hazily seen temporal to the disk.

Treatment $-200 \mathrm{mg}$. cortisone intramuscularly on the first day. Thereafter $200 \mathrm{mg}$. daily divided into two doses.

Course.-The anterior chamber was clear in 7 days and there was a slow but progressive clearing of the vitreous haze. After 10 days the focus showed definite evidence of subsiding but is not yet inactive; the vitreous haze still persists.

Case 5, O. S., aged 45 years.

Diagnosis. - Bilateral choroidal dystrophy.

Condition before Treatment.-Both eyes were white. Anterior segments normal.

Both fundi showed extensive choroidal haemorrhages involving both maculae.

Treatment.-100 mg. cortisone intramuscularly daily divided into two doses.

Course.- There was no apparent response to cortisone.

Case 6, E. W., aged 27 years.

Diagnosis.-Bilateral syphilitic interstitial keratitis.

Left Eye.--Interstitial keratitis in 1940, eye now quiet but showing a diffuse residual corneal scarring.

Right Eye.-Active interstitial keratitis began November, 1950. In January, 1951, a course of subconjunctival cortisone injections was given. There was a marked response and the condition became inactive within 4 weeks. After 14 weeks a relapse occurred.

Condition before Treatment.-The right eye was injected. There was a diffuse corneal haze, scattered keratic precipitates, and a mild aqueous flare. Vision was reduced from $6 / 9$ to $6 / 24$.

Treatment. $-10 \mathrm{mg}$. subconjunctival cortisone twice weekly.

Course.-There was a good response and the keratitis became inactive in 17 days.

Capillary permeability tests were carried out before, during, and after treatment of the relapse.

Case 7, A. C., aged 51 years.

Diagnosis.--Recurrent non-specific deep keratitis of the right eye.

Condition before Treatment.-The eye was moderately injected and very photophobic. A dense corneal infiltrate with a surrounding zone of faint corneal haze was present, and there was a faint aqueous flare.

Treatment.-Subconjunctival injection of $10 \mathrm{mg}$. cortisone at intervals of 4 days.

Course.- There was a marked improvement within 4 days and in 11 days the eye was white and quiet leaving a residual peripheral scar.

Case 8, L. W., aged 56 years.

Diagnosis.-Recurrent bilateral rosacea keratitis of 9 years' duration.

RIGHT EYE

Condition before Treatment.-The eye was mildly injected and slightly photophobic. The cornea showed bilateral scarring with superficial vascularization but there was no corneal staining.

Treatment.-Cortisone drops instilled hourly.

Course.-The eye was white and quiet in 7 days.

LEFT EYE

Condition before Treatment.--The eye was mildly injected and very photophobic.

The cornea showed diffuse corneal scarring with superficial vascularization and a small area of corneal staining was present temporally. 
Treatment.-Two injections of $10 \mathrm{mg}$. cortisone subconjunctivally followed by 2-hourly cortisone drops.

Course.-There was a marked improvement and the eye was white and quiet in 2 weeks.

Case 9, J. B., aged 43 years.

Diagnosis. - Bilateral perivasculitis retinae of 3 years' duration.

Condition before Treatment. - Right eye was white and the anterior chamber was clear but there was a dense vitreous haze which obscured the fundus. The left eye showed a dense aqueous flare and heavy vitreous haze was present which obscured the fundus.

Treatment. $-10 \mathrm{mg}$. cortisone subconjunctivally to both eyes twice weekly.

Course.-There was a slow but progressive clearing of both eyes. The aqueous flare in the left eye disappeared within two weeks and the vision had improved to $6 / 18$ in both eyes in 2 months.

Case 10,'D. D., aged 26 years.

Diagnosis.-Bilateral rosacea keratitis of 3 years' duration.

\section{RIGHT EYE}

Condition before Treatment.-The eye was much injected and very photophobic. The cornea showed dense peripheral scarring with superficial vascularization, and a large staining area was present at the nasal periphery. The anterior chamber showed no cells or flare.

Treatment.-10 mg. cortisone subconjunctivally twice weekly.

Course. - The eye showed a definite symptomatic improvement and became white in 8 days, but there has so far been no change in the staining area.

LEFT EYE

Condition before Treatment.-The eye showed mild injection with slight photophobia. Dense peripheral scarring with superficial vascularization was present in the cornea and there were scattered punctate areas of staining at the lower periphery. The anterior chamber showed no cells or flare.

Treatment.-Cortisone drops given hourly.

Course. - The eye became white and quiet within 7 days but the punctate areas of staining were and are still present.

\section{Discussion}

The results obtained from the individual capillary permeability curves are summarized in the Table (overleaf). The permeability curves of Case 7, treated with subconjunctival cortisone, are typical examples (Fig. 2a, $b, c)$. Fig. $3 a, b, c$ shows the same curves with the ampère readings converted into absolute readings of fluorescein. Further examples are shown in Fig. $4 a, b, c$ (Case 1, treated with systemic cortisone), and in Fig. $5 a, b, c$ (Case 8 , right eye treated by cortisone drops, left eye by subconjunctival injections and drops).

It will be observed that in ten of the thirteen eyes showing clinical evidence of inflammation the relative concentrations of fluorescein in the aqueous were lowered. Of the three eyes showing no change, there was a marked delay in the entrance of fluorescein into the anterior chamber of one, and the inflammatory manifestations in the remaining two were confined to the fundus, the anterior segment showing no evidence of involvement. In Case 5, which showed only degenerative choroidal changes, there was also no change in capillary permeability. It is noteworthy that cortisone therapy influenced the capillary permeability in none of the five eyes showing no evidence 
TABLE

RESULTS IN TEN CASES

\begin{tabular}{|c|c|c|c|c|c|c|}
\hline \multirow{2}{*}{$\begin{array}{l}\text { Case } \\
\text { No. }\end{array}$} & \multirow{2}{*}{ Eye } & \multirow{2}{*}{ Diagnosis } & \multirow{2}{*}{ Treatment } & \multirow{2}{*}{ Clinical Course } & \multicolumn{2}{|c|}{$\begin{array}{c}\text { Capillary Permeability Curve } \\
\text { compared with Pre-Treatment Curve }\end{array}$} \\
\hline & & & & & $\begin{array}{c}\text { During } \\
\text { Treatment }\end{array}$ & After Treatment \\
\hline 1 & $\begin{array}{l}\text { Right } \\
\text { Left }\end{array}$ & $\begin{array}{l}\text { Acute choroiditis } \\
\text { Normal }\end{array}$ & $\underset{i}{\text { Cystemic }}$ & $\begin{array}{l}\text { Marked } \\
\text { improvement } \\
\text { Unchanged }\end{array}$ & $\begin{array}{l}\text { Markedly } \\
\text { depressed } \\
\text { Unchanged }\end{array}$ & $\begin{array}{l}\text { Slightly depressed } \\
\text { Slightly elevated }\end{array}$ \\
\hline 2 & $\begin{array}{l}\text { Right } \\
\text { Left }\end{array}$ & $\begin{array}{c}\text { Perivasculitis } \\
\text { retinae }\end{array}$ & $\begin{array}{l}\text { Systemic } \\
\text { cortisone }\end{array}$ & $\begin{array}{l}\text { Slight } \\
\text { improvement }\end{array}$ & $\begin{array}{l}\text { Slightly } \\
\text { depressed }\end{array}$ & $\begin{array}{l}\text { Elevated } \\
\text { Returned to pre-treat- } \\
\text { ment level within } \\
\text { limits of error }\end{array}$ \\
\hline 3 & $\begin{array}{l}\text { Right } \\
\text { Left }\end{array}$ & $\begin{array}{l}\text { Acute choroiditis } \\
\text { Normal }\end{array}$ & $\begin{array}{l}\text { Systemic } \\
\text { cortisone }\end{array}$ & $\begin{array}{l}\text { Marked } \\
\text { improvement } \\
\text { Unchanged }\end{array}$ & Unchanged & - \\
\hline 4 & $\begin{array}{c}\text { Right } \\
\text { Left }\end{array}$ & $\begin{array}{l}\text { Acute choroiditis } \\
\text { Normal }\end{array}$ & $\begin{array}{l}\text { Systemic } \\
\text { cortisone }\end{array}$ & $\begin{array}{l}\text { Slight } \\
\text { improvement } \\
\text { Unchanged }\end{array}$ & $\begin{array}{l}\text { Depressed } \\
\text { Unchanged }\end{array}$ & - \\
\hline 5 & $\begin{array}{c}\text { Right } \\
\text { Left }\end{array}$ & Choroidal & $\begin{array}{l}\text { Systemic } \\
\text { cortisone }\end{array}$ & Unchanged & Unchanged & - \\
\hline 6 & Right & $\begin{array}{r}\text { Active interstitial } \\
\text { keratitis }\end{array}$ & $\begin{array}{c}\text { Subconjunctival } \\
\text { cortisone }\end{array}$ & $\begin{array}{l}\text { Marked } \\
\text { improvement }\end{array}$ & $\begin{array}{l}\text { Slightly } \\
\text { depressed }\end{array}$ & $\begin{array}{l}\text { Returned to pre-treat- } \\
\text { ment level within } \\
\text { limits of error }\end{array}$ \\
\hline & Left & $\begin{array}{l}\text { Inactive specific } \\
\text { keratitis }\end{array}$ & Untreated & Unchanged & Unchanged & Unchanged \\
\hline 7 & $\begin{array}{l}\text { Right } \\
\text { Left }\end{array}$ & $\begin{array}{l}\text { Non-specific deep } \\
\text { keratitis } \\
\text { Normal }\end{array}$ & $\begin{array}{l}\text { Subconjunctival } \\
\text { cortisone } \\
\text { Untreated }\end{array}$ & $\begin{array}{l}\text { Marked } \\
\text { improvement } \\
\text { Unchanged }\end{array}$ & $\begin{array}{l}\text { Depressed } \\
\text { Unchanged }\end{array}$ & $\begin{array}{l}\text { Returned to pre-treat- } \\
\text { ment level } \\
\text { Unchanged }\end{array}$ \\
\hline 8 & $\begin{array}{l}\text { Right } \\
\text { Left }\end{array}$ & i Rosacea & $\begin{array}{c}\text { Cortisone drops } \\
\text { Subconjunctival } \\
\text { cortisone and } \\
\text { cortisone drops }\end{array}$ & $\begin{array}{l}\text { Marked } \\
\text { improvement }\end{array}$ & $\begin{array}{r}\text { Moderately } \\
\text { depressed }\end{array}$ & Slightly elevated \\
\hline 9 & $\begin{array}{l}\text { Right } \\
\text { Left }\end{array}$ & $\begin{array}{l}\text { Perivasculitis } \\
\text { retinae }\end{array}$ & $\begin{array}{c}\text { Subconjunctival } \\
\text { cortisone }\end{array}$ & $\begin{array}{l}\text { Slow } \\
\text { improvement }\end{array}$ & $\begin{array}{l}\text { Unchanged } \\
\text { Markedly } \\
\text { delayed }\end{array}$ & $\begin{array}{l}\text { Slightly elevated } \\
\text { Returned to pre-treat- } \\
\text { ment level within } \\
\text { limits of error }\end{array}$ \\
\hline 10 & $\begin{array}{l}\text { Right } \\
\text { Left }\end{array}$ & Rosacea & $\begin{array}{c}\text { Subconjunctival } \\
\text { cortisone } \\
\text { Cortisone drops }\end{array}$ & $\begin{array}{l}\text { Marked } \\
\text { i improvement }\end{array}$ & Depressed & -- \\
\hline
\end{tabular}

of inflammatory involvement. It will also be observed that the depression of the capillary permeability is independent of the route of administration. In six patients, capillary permeability curves were recorded after the cessation of cortisone therapy, and ten of the twelve eyes showed an increase in the entry of fluorescein above that noted during treatment, although the ocular inflammation appeared to be clinically quiescent. Of the remaining two eyes which showed no change, one had received no treatment and the other had shown no evidence of inflammatory involvement before cortisone therapy.

The results obtained in this series of cases apparently demonstrate that cortisone is instrumental in reducing the pathologically raised capillary permeability, but we recognize that the reduction might 
well be secondary to the inhibition of the inflammatory tissuereaction rather than a direct result of the influence of cortisone on the

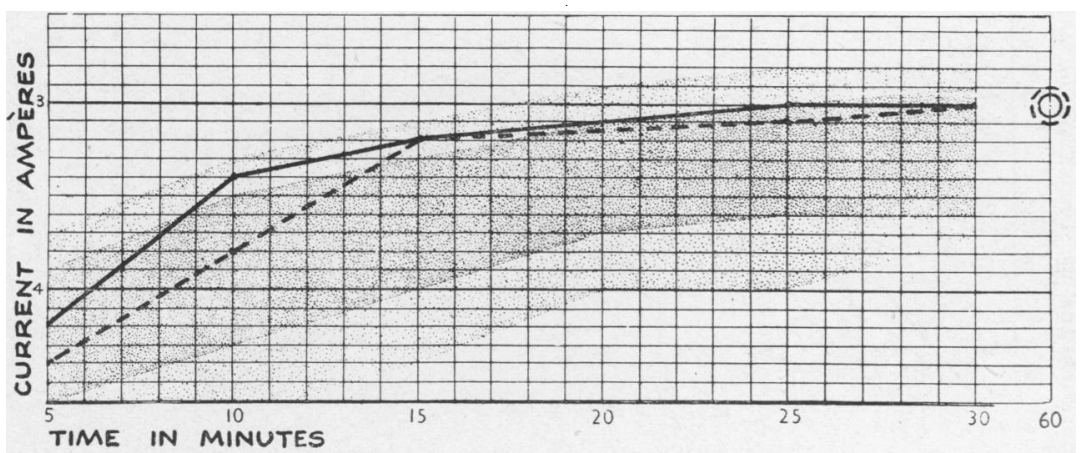

FIG. $2(a)$

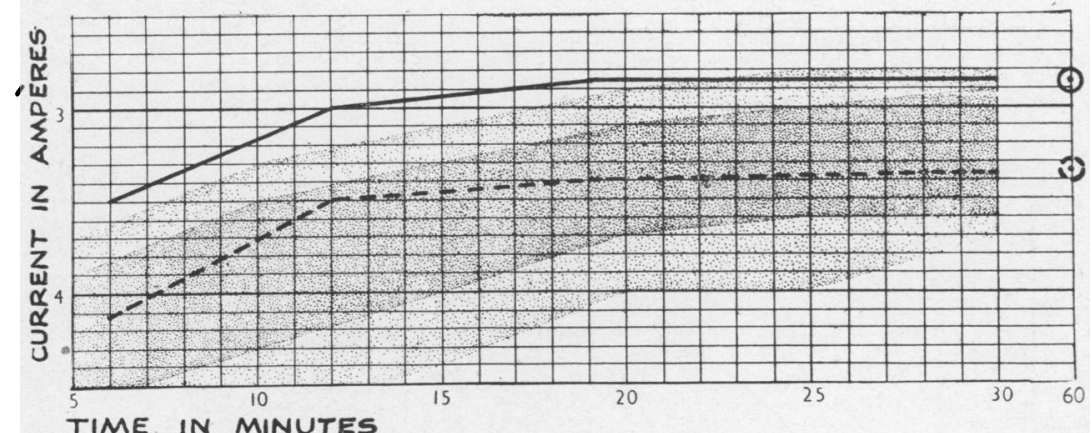

FIG. $2(b)$

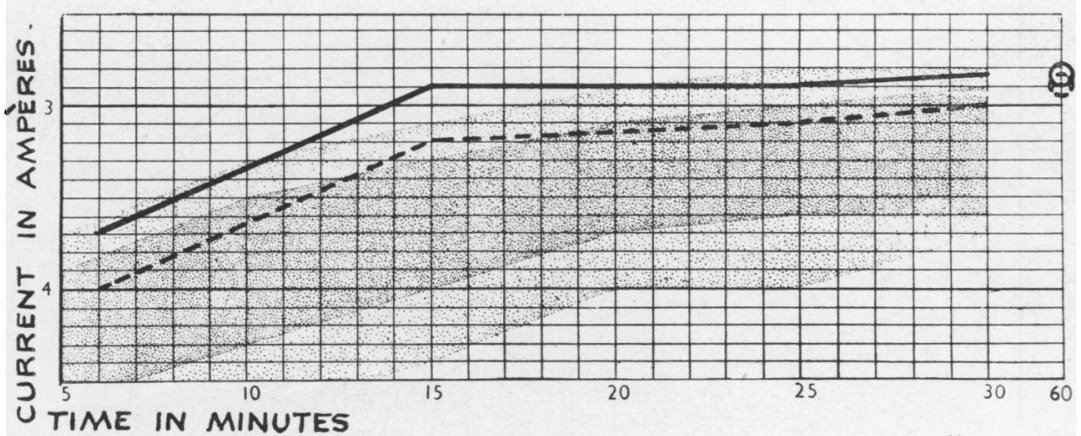

FIG. $2(c)$

FIG. 2.-Recurrent non-specific deep keratitis of the right eye (Case 7, deep keratitis). Capillary permeability curves: (a) before, (b) during, (c) 9 weeks after cortisone treatment by subconjunctival injection. Continuous line and circle, left eye; broken line and circle, right eye. 


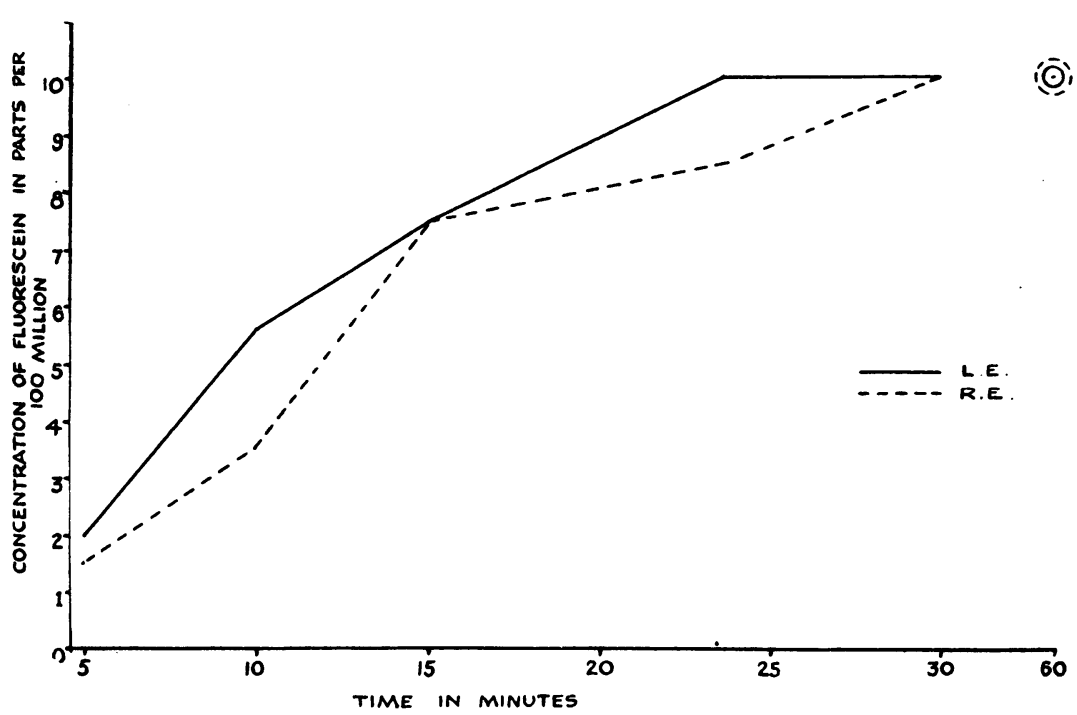

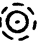

FIG. 3 (a)

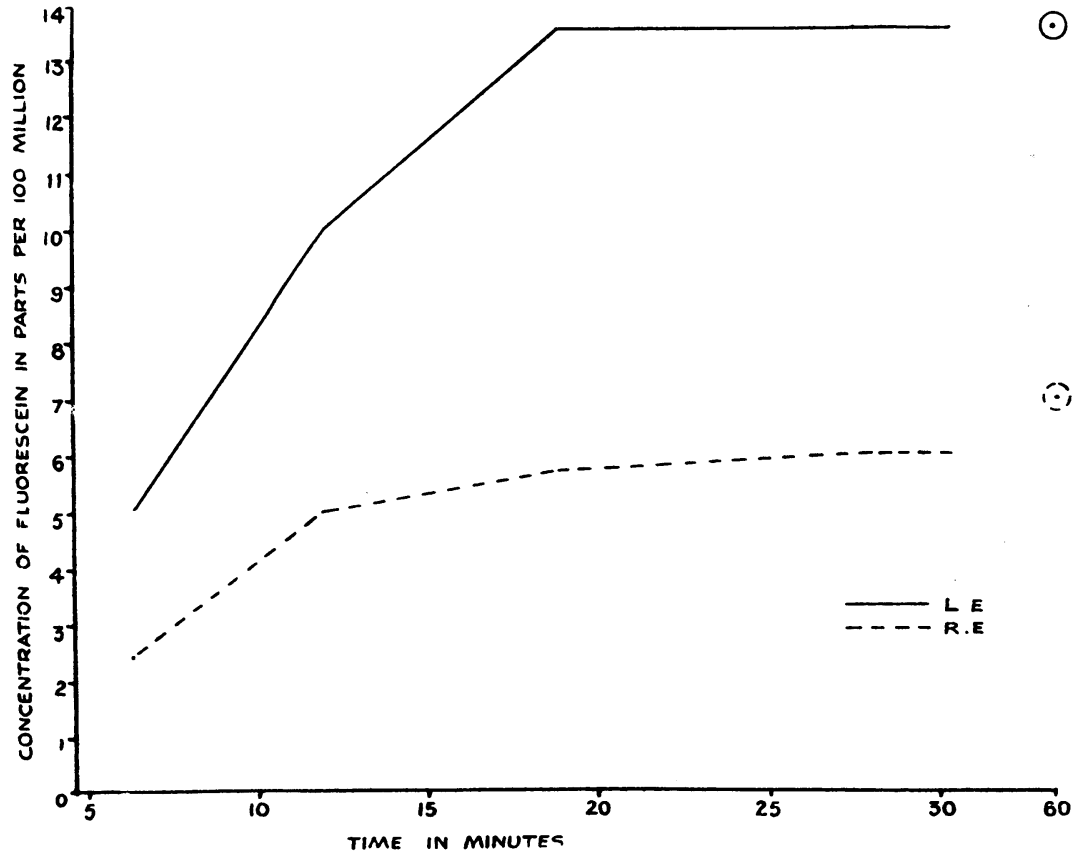

$\odot$

Fig. 3 (b) 


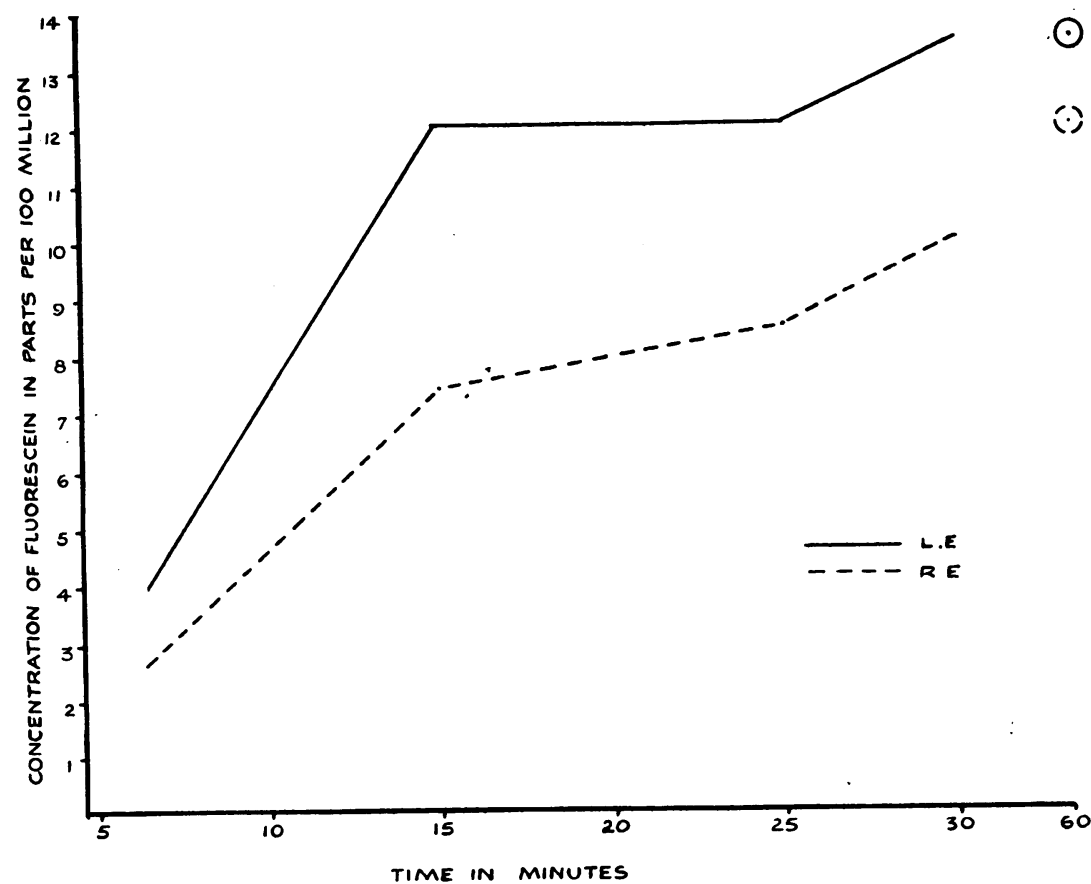

Fig. 3 (c)

FIG. 3.-Case illustrated in Fig. 2. Absolute concentrations of fluorescein: (a) before, (b) during, (c) 9 weeks after cortisone treatment by subconjunctival injection.

Continuous line and circle, left eye; broken line and circle, right eye.

capillary wall. The permeability curves recorded in six cases after the withdrawal of cortisone show, however, that the capillary permeability tends to increase after treatment has been discontinued, although in each patient the ocular condition was clinically quiescent. This would appear to indicate that the preliminary fall in permeability obtained during treatment may be independent of the associated inflammatory manifestations.

The possibility of the persistence of a residual sub-clinical inflammatory reaction cannot, however, be completely excluded. The existence of this possibility is demonstrated by Case 6 , in which a relapse occurred after the withdrawal of cortisone, the basic inflammatory diathesis having presumably been uninfluenced.

\section{Conclusions}

The results obtained in these investigations indicate that the capillary permeability in the normal human eye is not influenced by 
FIG. 4.-Case 1 (acute choroiditis, right eye). Fluorescein curves: $(a)$ before cortisone treatment, $(b)$ during cortisone treatment given systemically: at this stage the permeability was lower than could be recorded on the chart up to 30 min., (c) 6 weeks after cortisone treatment. Conversion readings into absolute concentration between 30 and 60 minutes shown circled on the right.

Continuous line and circle, left eye; broken line and circle, right eye.

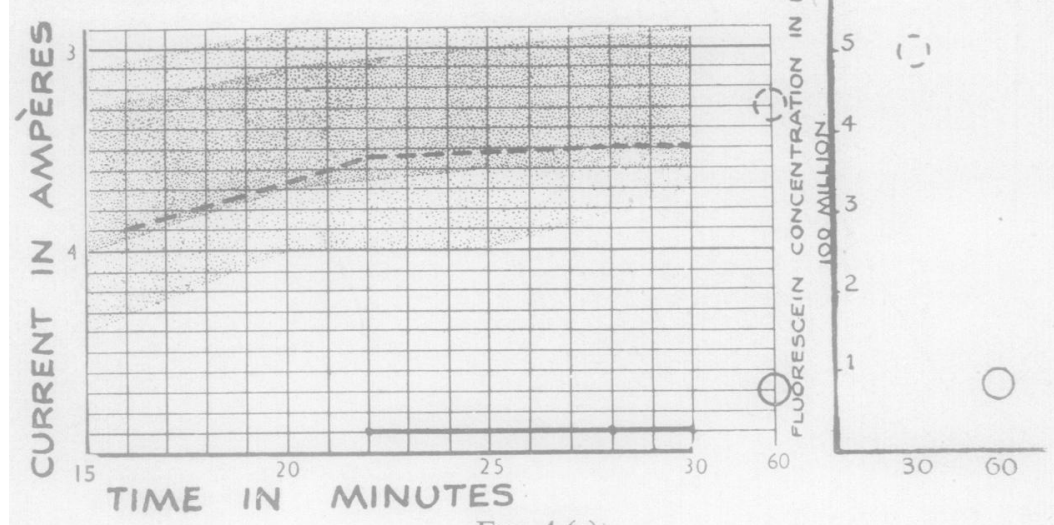

FIG. $4(a)$

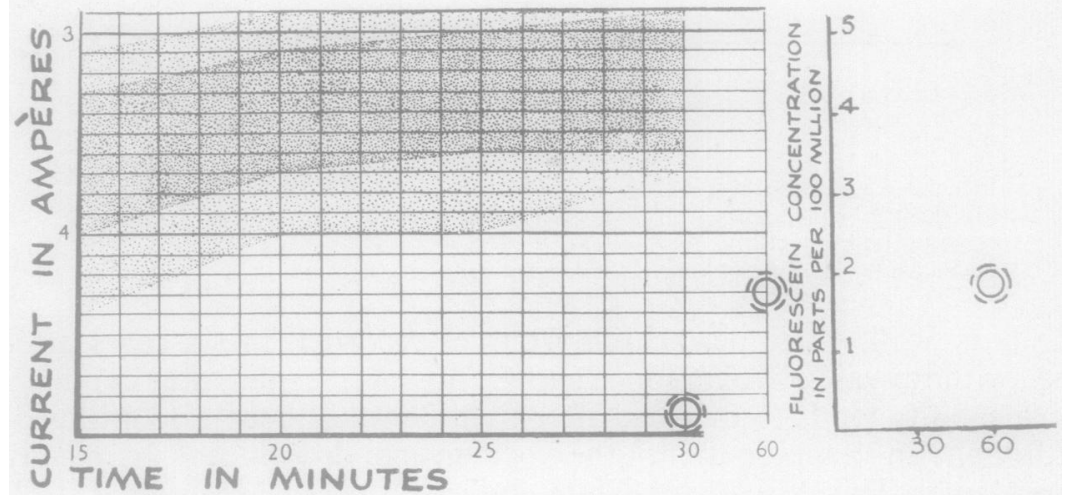

FIG. $4($ b)

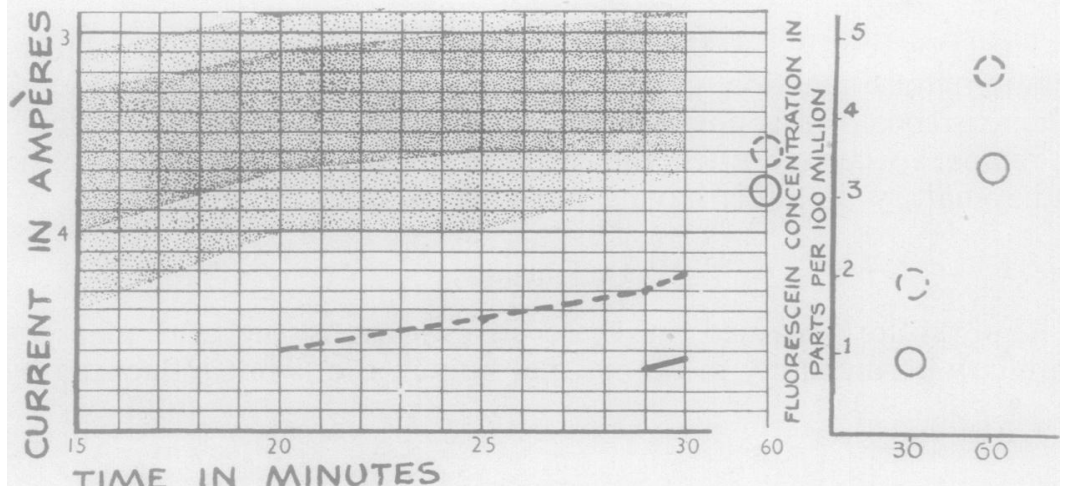

FIG, $4(c)$ 


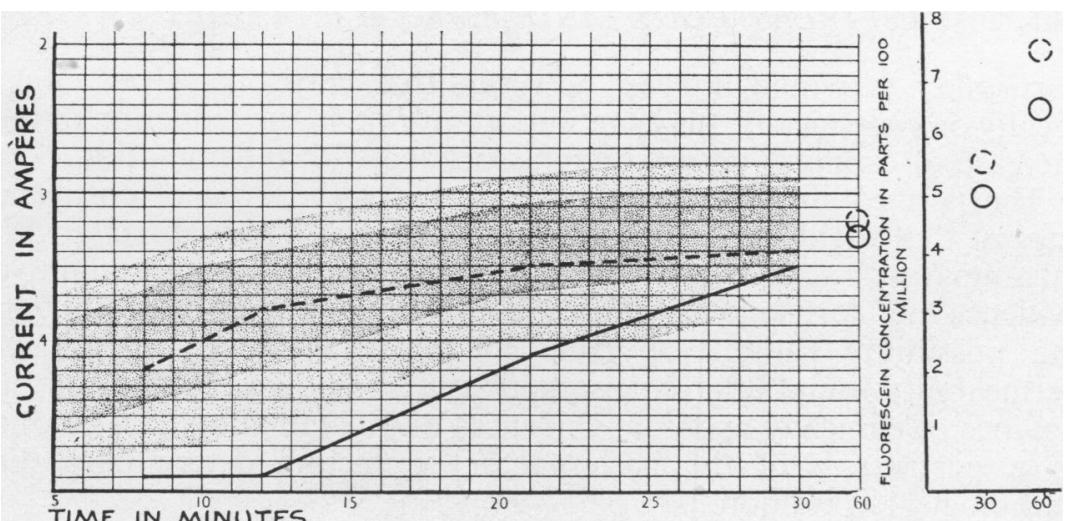

FIG. $5(a)$
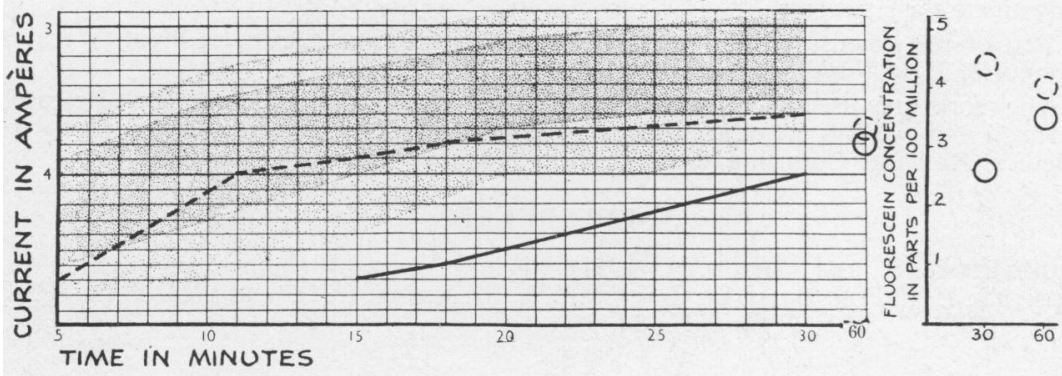

FIG. $5(b)$

FIG. 5.- Case 8 (bilateral rosacea keratitis). Fluorescein curves: (a) before cortisone treatment, (b) during cortisone treatment by instillation of drops in right eye and subconjunctival injection in left eye, (c) 4 weeks after cortisone treatment. Curves show capillary permeability; conversion readings into absolute concentrations between 30 and 60 minutes shown circled on the right.

Right eye (drops), broken line and circle; left eye (subconjunctival injection), continuous line and circle.
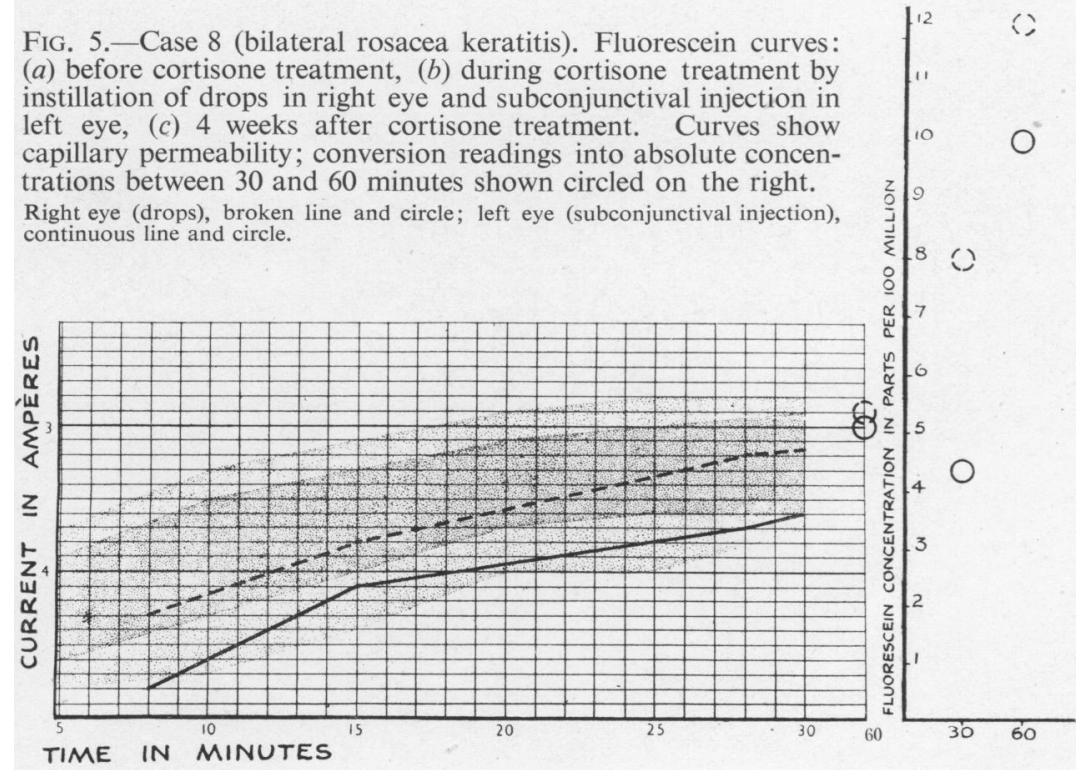

FIG. $5(c)$ 
cortisone. It would appear, however, that cortisone, given either locally or systemically, plays an important role in the reduction of the increase of capillary permeability associated with inflammation.

The permeability curves taken after the withdrawal of cortisone suggest that the decrease in permeability does not vary directly with inflammatory activity. This may be regarded as presumptive evidence that cortisone has a direct action on the capillaries, although the possibility cannot be excluded that the rapid increase of permeability found after cortisone treatment had ceased, and in the absence of clinically apparent evidences of inflammation may be due to a persistence of the basic factor or factors determining the pathological condition.

We are greatly indebted to Sir Stewart Duke-Elder and Dr. Norman Ashton for invaluable advice and guidance in the preparation of this paper, and to the surgeons of the Moorfields, Westminster and Central Eye Hospital for permission to treat and investigate their patients.

Part of the expense of this research was defrayed by the Alexander Pigott Wernher Memorial Trust Fund.

The cortisone used in this investigation was supplied by the Medical Research Council and was in part derived from a gift from Merck and Co. made jointly to the Medical Research Council and the Nuffield Trust.

\section{REFERENCES}

Duke-Elder, S., and Ashton, N. (1951). British Journal of Ophthalmology, 35, 695.

Leopold, I. H., Purnell, J. E., Cannon, E. J., Steinmetz, C. G., and McDonali, P. R. (1951). Amer. J. Ophthal., 34, 361. 